\title{
An imagined community Twenty-five years of Nordic Museology
}

In a recent talk on art in cultural history museums the German art historian and museum practitioner Michael Fehr talked about the direction of objects. All objects, he claimed, except maybe spheres and cubes, have a direction. They are heading in definite directions. At a very practical level, Fehr argued, arranging objects in museums should consider both the objects' vectors and the position of the viewer. In a more general sense, theories of objectivity and subjectivity, of directions of matter and sight, are important for the ways museums communicate. For 25 years, this journal has been delivered to addresses in the Nordic countries. For most of this period, it has been sent out by Museumstjenesten in Denmark. In what collections has the journal arrived? How have the recipients perceived its direction? How has the journal come to matter as an object on desks and bookshelves, in libraries and on museum counters? We, the editorial team, like to think that it has had a direction, and that the intentions of the initiators have been discernible as the subscribers have received their issues.

The first issue of Nordic Museology was published in 1993. The intention, the preface stated, was to establish a Nordic forum for research and debate. The initiators wanted to create an "open channel between theory and practice" and hoped to "ensure that research and education continuously can draw nourishment from practice". The first editors, Jon Aage Gjestrum from Norway, Per-Uno Ågren from Sweden, and Ole Strandgaard from Denmark were forceful proponents of museum practice based on theory and of museological research based on practice. For the next issue, they were joined by Janne Vilkuna from Finland, and later Bjarni F. Einarsson from Iceland. This editorial team worked continuously to keep the channel between practice and theory open, and to establish new ones. Even as editorial teams have changed during the past 25 years, this has remained the main trajectory of the journal. The articles we print are written by employees in museums and cultural heritage institutions as well as in academia, and our readers also seem to be evenly distributed over a host of different institutions.

The initiators wanted to create a forum. Eva Silvén, who has served Nordic Museology as member of the editorial board, Swedish editor and not least as a writer, defined the journal as a "permanent virtual conference". The journal has created bonds between museum professionals and academics in the Nordic countries and built a Nordic community. In his seminal work on nationalism from 1983, historian Benedict Anderson coined the term "imagined communities". The nation, he claimed, is produced through various socio-political forces, and among them media is instrumental in installing a sense of 
community among people who will never meet face to face. The emotional attachment and investments in Nordic Museology are definitely not comparable to national sentiments, but the journal, as a communication media, build community. In the first issue, the editors stated that the language of the journal would be Danish, Norwegian, Swedish and English, the languages commonly understood in the Nordic countries. They further stated that "despite their close ties to the development of European museums, the Nordic countries clearly have a common understanding of history and cultural heritage." This understanding was based on a tradition shaped by mutual influences and similarities in societal development. The claim was that there was, and we can infer, there should further be developed a Nordic museology.

\section{NORDIC: HIP OR DUSTY}

In the first article in this journal Mattias Ekman presents a Nordic take on the Kunstkammer tradition in the seventeenth century, an important topic from the very first years of Nordic Museology. His bold claim is that this tradition lies at the heart of the museology, museography, and purpose-built architecture and furniture which constitute the Nordic museum. "Norden" and the "Nordic" have undergone deep transformations since the seventeenth century: the concepts cover different territories and are used for different purposes when used to depict the Great Nordic War (1700-1721) or the Nordic Council (established 1952). The attempt to forge the Nordic into an imagined community is thus a later phenomena, but Ekman shows the value of working with Norden as an analytical unit as early as in the seventeenth century.

Our amibition is international, the first editors of Nordic Museology stated. "On the one hand, we will communicate texts of museological interest from language areas that are not particularly well known in the Nordic countries, particularly from France and Germany; on the other hand, we will disseminate Nordic thinking abroad through English summaries of the Scandinavian texts." Over the years, this ambition has led to the printing of a long range of both museological classics and new texts by contemporary authors. The international profile appears to have been more important for the first ten years of the journal than it has been in later years. The first editors had an international outlook and were active in global organizations, and the journal served as a node in international museological exchange. In his article about the conceptualization of a Nordic museology in 1990s, Mattias Bäckström traces how the concept was coined and developed by the milieu in Umeå in response to international museological debates. This gives yet again another perspective of how the imagined community of Nordic museologies was formed and developed.

The editorial continutity of this journal has been strong. Only three main editors have served at the helm, Per-Uno Ågren until 2004, Ane Hejlskov Larsen from 2005 to 2012, and the present editor since 2013. One of the members of the editorial team, Janne Vilkuna, has been active since the first year. In the national editorial boards, many have served long terms, and their commitment has vitalized the community. Our authors and contributors have also been remarkably faithful. In this issue, we are happy that Bjørnar J. Olsen has contributed with a thought-provoking article on the value of collections. His articles in Nordic Museology, from the first issue on, have become classics, and his and our other authors' 
contributions to build knowledge cumulatively have been of fundamental importance to the journal. It has been claimed, and rightly so, that texts on and research about museums have had a tendency to invent the wheel again and again. Strengthening the familiarity with earlier museological research as a means to develop and deepen our understanding of museums and heritage, remains an important task for the journal. The degree to which this is actually taking place is proof of its success.

However, the world has changed. New issues demand new theorizations and perspectives. Lizette Gradén and Tom O’Dell present the idea of hip heritage in their article on the packaging of the Nordic in the American cultural market, exemplified by two North American institutions, the American Swedish Institute and the Nordic Heritage Museum. They problematize the manner in which elements of Nordic history and identity are being re-thought and re-framed in the cultural and economic context of the American heritage market. The Nordic is not what it was, and Nordic heritage have to meet current demands. Our last regular article in this issue takes an opposite position, posing what might be seen as the eternal problem of museums: Why is dust in a museum so appalling, and, consequently, what do people really mean by the word pair dusty museum? Inkeri Hakamies takes a fresh look at an ubiquitous phenomenon and a practical problem which is rarely given an analytical treatment.

\section{EDITORIAL BRIEFS: MAPPING THE COMMUNITY}

How has the Nordic museum field changed, and what has been the role of museology during the lifetime of the journal? In a separate section, the editorial team, consisting of one

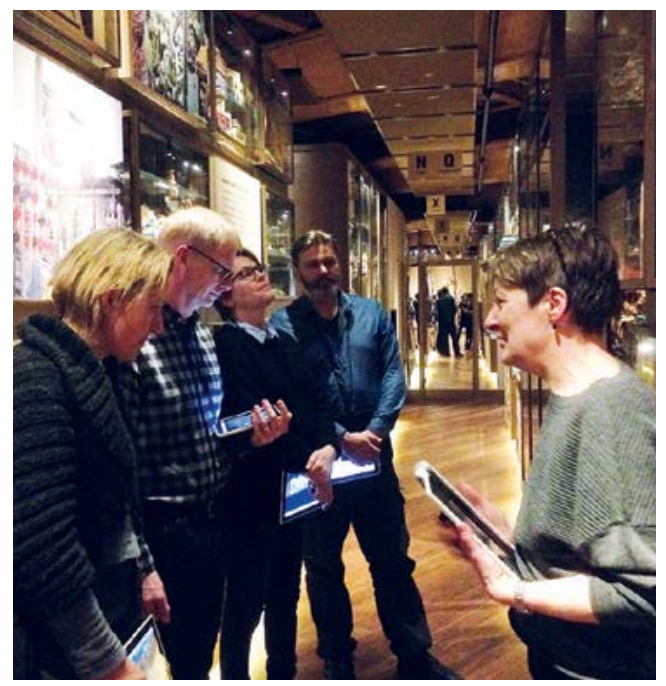

Fig. 1. The editorial team visiting the exhibition Magasinet (The Store) at the Museum of Ethnography in Stockholm, in connection with the annual board meeting 2016. From the left: Anne-Sofie Hjemdahl, Allan Risbo, Brita Brenna, Sigurjón Hafsteinsson. To the right museum director Lotten Gustafsson Reinius. Photo: Eva Silvén.

editor from each of the five Nordic countries, present their perspectives on the general claim of the first editors: is there such a thing as a common Nordic understanding of history and cultural heritage? More specifically: can we see similarities in museum policies and organisation? We have left it to the readers to compare. The editors themselves have been asked simply to present very brief narratives on the development of museology as an academic subject and research field in their respective countries.

Have we mapped the museums and museologies in convincing manners? Most certainly, much remains to be said. One future ambition would be to step back from the national and develop a Nordic perspective on the field. To what extent are governmental 
measures and policies developed through reciprocal influences? Is there a Nordic museum policy, and what are the forces that have shaped it? How are museum professionals developing their strategies and visions for collection, preservation and communication through meetings and co-operations? What arenas serve Nordic interaction, and what decides which practices travel across borders? We could investigate registration technologies from the early twentieth century onwards, the development of digital solutions like Digitalt Museum, collecting and collaborative projects like Samdok etc. Some of these are success stories of transnational Nordic collaborations, others are examples of national or even decidedly local projects. A truly Nordic perspective can give one direction for Nordic museology in the years to come.

\section{Short Cuts: Challenging THE COMMUNITY}

In the last section of this issue, nine authors from the Nordic countries present their visions of what museology is and does. As academics, museum professionals, or both, they have been given free reins and a limited number of words to address what they envision museology to be and what they would wish for its future. Their answers are encouragingly different. There seems to be no danger of Nordic museology stiffening into a pose of a one-eyed monster. Our community retains a broad, reflexive and inclusive perspective on museology. However, as the editors of Nordic Museology, we must take responsibility for the lack of perspectives from minority positions. We have not been able to include or encourage writers outside the power institutions that we ourselves inhabit: museums, heritage management and academia.

Coming back to the vision of trajectories, an important ambition for years to come is to challenge the Nordic in more fundamental ways and our terms and conditions for thinking we are the same. Who "we" might be.

Finnally, this journal would not have survived without the economical contribution from a range of national and Nordic institutions. Presently the journal is financed by the The Joint Committee for Nordic research councils in the Humanities and Social Sciences, through the sub-committee financing Nordic Periodicals. The journal is absolutely dependent on this support. Museumstjenesten in Denmark has kept the journal on track, securing the printing and serving subscribers for decades. Allan Risbo has organized our meetings, securing the good ambience and a forum for important discussions.

In the final instance, Nordic Museology has been kept alive by a large group of people who have given their valuable time to the journal: the hundreds of authors that have given the journal the content, my current colleagues in the editorial team, Janne Vilkuna, Gudrún D. Whitehead, Vinnie Nørskov and Fredrik Svanberg, all the previous members of the editorial boards, the peer reviewers who have reviewed hundreds of articles during the years, and not least the readers. Without this very real community we would not have been able to make out a direction. Thank you all!

Brita Brenna 